\title{
Strategi Pengembangan Daya Tarik Kota Lasem Sebagai Kota Batik-Kopi
}

\author{
Tangguh Okta Wibowo \\ Sekolah Pascasarjana, Universitas Gadjah Mada \\ tangguhow@yahoo.com
}

\begin{abstract}
This article explores about the tourism potency of Lasem city, a district located in Rembang Regency, Central Java. Data are collected from information circulating on the internet, some testimonials from blogs, and also observations from researchers directly. This article uses city branding theory to explore tourist destination and to maximize the potential things that can be developed. From the results of discussion, the strategies for developing Lasem city to attract many visitors are to formulate a new city branding for Lasem city supported by the development of infrastructure for supporting a city branding: the Lasem as Batik-Coffee City.
\end{abstract}

Keywords: batik; city branding; coffee; Lasem city; and lelet 


\section{PENGANTAR}

Tulisan ini mengangkat sebuah kota di Jawa Tengah, yaitu kota Lasem. Kota Lasem adalah salah satu kecamatan di Kabupaten Rembang, Jawa Tengah. Kota ini merupakan kota terbesar kedua di Kabupaten Rembang setelah kota Rembang. Secara Geografis, letak dari kota ini di pesisir Utara pantai Jawa dan dilintasi jalur pantura. Selama 24 jam jalur pantura ini ramai dilewati kendaraan baik dari dalam ataupun luar kota. Jantung kota Lasem berada pada titik, yaitu pertemuan pertigaan jalan pantura, jika ke Selatan menuju kota Pancur, ke Timur ke Surabaya dan ke Barat ke Semarang. Sebagai tujuan pariwisata, kota ini sering dikenal dengan produksi batik tulis dan budaya mengopi atau lebih dikenal dengan istilah 'lelet'.

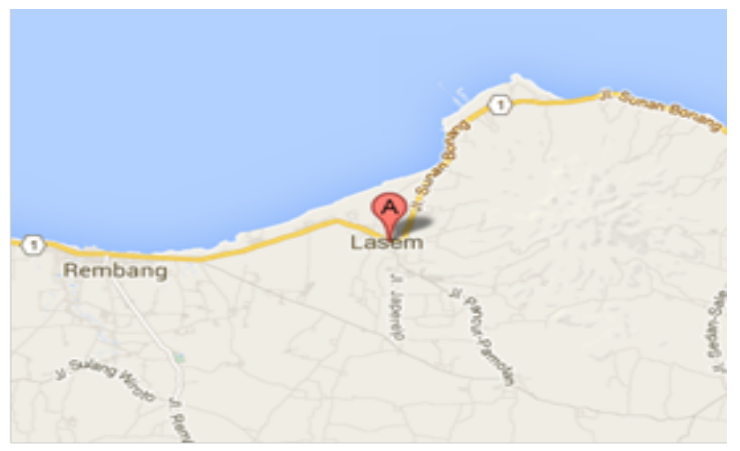

Gambar 1.

Peta Kota Lasem

Pada kenyataannya brand yang sudah melekat pada kota Lasem ini belum dapat membuat kota ini menjadi terkenal seperti kota yang memiliki ciri khas sendiri, seperti Jogja Never Ending Asia, Bandung Paris Van Java, Batu Kota Wisata, dan lainnya. Akan tetapi, wisatawan yang datang ke Lasem juga masih belum 'mapan' bila dibandingkan dengan kota-kota besar di atas. Apalagi jika dikaitkan dengan kota yang juga memiliki ciri khas sebagai penghasil batik, yaitu Pekalongan. Tujuan dari tulisan ini adalah menganalisis potensi strategis kota Lasem sebagai destinasi pariwisata, serta beberapa rekomendasi untuk strategi dan program pengembangan sebagai daya tarik wisata di kota Lasem, yaitu terkait city branding.

\section{METODE DAN TEORI}

Studi ini mempergunakan metode analisis deskriptif, yaitu dengan mengumpulkan beragam data dan berkembang melalui media baru, yaitu internet. Berbagai informasi yang berkembang tentang kota Lasem dipergunakan untuk mendeskripsikan kota Lasem dan kemudian dianalisis sesuai dengan pisau analisis yang digunakan, misalnya berita yang berkembang di website, liputan di Youtube, dan testimoni di blog. Termasuk wikipedia, pertimbangannya karena tulisan wikipedia juga dari penulis yang berasal dari Lasem, artinya tulisan yang berasal di blog maupun wikipedia juga berasal dari opini masyarakat dan akan menyebar informasi ini kepada pembacanya (dalam hal ini konsepnya seperti konsep marketing mouth-tomouth). Fokus dari studi ini adalah mengeksplorasi beragam informasi terkait kota Lasem. Artinya informasi inilah yang nantinya berkontribusi dalam membangun city branding sebuah daerah/kota. Saya juga melakukan observasi dalam melihat keseharian masyarakat kota Lasem pada saat pergi ke warung kopi.

Sebagai kerangka teori, penelitian ini fokus kepada strategi pengembangan city branding apa yang dapat dipertimbangkan sebagai rekomendasi bagi kota Lasem. Branding memiliki banyak keuntungan, termasuk mengurangi resiko pembelian konsumen, membangun kewaspadaan dengan mengkomunikasikan pesan yang 
konsisten, menyemangati untuk mendorong konsumen datang kembali dan menumbuhkan keloyalan dan asosiasi dengan kota dengan identitas unik (Kolb, 2006:219). Pemilihan brand ini juga tidak semata dalam membuat sebuah jargon atau tagline kepada sebuah kota, tapi brand lebih dari sebuah identitas yang dapat menggugah respon dari persepsi pengunjung untuk menopang keuntungan baik itu di sektor industri, ekonomi dan juga pariwisata. Brand yang baik, dimunculkan ketika brand tersebut sudah melekat di masyarakat dan terbentuk melalui sejarah dan proses yang lama. Bagaimana dimulai dari kesan dan komentar pengunjung. Menurut Pike, sebuah brand harus hadir karena sesuatu janji kepada konsumen, sehingga lebih dari hanya simbol-simbol yang dihadirkan kepada publik. Brand sangat bermanfaat untuk mempertimbangkan brand dalam mempresentasikan sebuah identitas dari produsen dan sebuah citraan untuk konsumen (2008:179). Memang tidak bisa dipungkiri jika sebuah kota memerlukan gaya hidup masyarakat dalam membuat branding yang kuat dan sukses melekat pada kota tersebut. Dalam membuat brand yang berbeda dan melekat pada suatu kota haruslah dapat menginspirasi para wisatawan, industri sekitar, terutama masyarakatnya sendiri. Lebih lanjut, sebuah konsep yang sering dibingungkan saat branding adalah penempatan posisi (positioning). Konsepnya serupa, namun ada perbedaan yang penting. Branding sebagai citraan dari sebuah kota, sedangkan penempatan posisi lebih kepada bagaimana konsumen membedakan produk dengan produkproduk yang sama (Kolb, 2006:228). Gagasan kunci pada penempatan posisi adalah citra brand, Bagaimana pun juga penempatan posisi memerlukan pemahaman yang lebih tentang citra brand apa yang ada pada pikiran konsumen (Pike, 2008:221).

Peran serta masyarakat juga turut membantu proses ini. Pengimplementasian program pengembangan pariwisata bertujuan memaksimalkan potensi masyarakat setempat yang dapat dilihat dari peningkatan fungsi-fungsi usaha pariwisata berbasis masyarakat (community based tourism atau CBT). Model ini mengakomodasi keterlibatan masyarakat dalam proses perencanaan, pengelolaan, dan evaluasi daya tarik wisata (Putra, 2015; Mastika, 2018).

\section{HASIL DAN PEMBAHASAN}

\section{Sejarah Batik Kopi}

Sejak zaman dahulu kota Lasem ini dikenal dengan sebutan kota Santri. Terdapat beberapa peninggalan pesantren tua di kota ini yang dapat dikunjungi hingga sekarang. Banyak ulama karismatik yang wafat di kota Lasem. Seperti Sayid Abdurrahman Basyaiban (Mbah Sambu) yang kini namanya dijadikan jalan raya yg menghubungkan Lasem-Bojonegoro, $\mathrm{KH}$. Baidhowi, KH. Khalil, KH. Maksum, KH. Masduki dan lainnya. Sehingga Lasem dijuluki sebagai kota santri, mengingat banyaknya ulama, Pondok Pesantren dan jumlah santri yang belajar agama islam di kota ini (Wikipedia, 2013a).

Mengingat Lasem sebagai kota santri tak heran banyak berdiri beberapa warung kopi. Menurut KH. Mustofa Bisri (Gus Mus), sejarah kopi lelet Rembang tak lepas dari sejarah pesantren, karena sejak dulu, kiai, dan santri maniak kopi (Irin 2013). Perkembangan yang sangat pesat dan menjamur adalah di kawasan kota Lasem, bagaimana bisa ditemukan beberapa pondok yang sebelahnya warung kopi. 
Meskipun demikian, jika ditinjau dari sosial-budaya masyarakat Lasem, sejak dalu masyarakat Lasem biasa membatik dan sampai sekarang masyarakat Lasem pun masih membatik. Jelas membatik dan lelet (membatik kopi) ini mempunyai hubungan dekat, yaitu sama-sama mengekspresikan motif-motif melalui suatu media dengan menggunakan tinta yang khas. Ibaratnya jika pada batik menggunakan media kain mori dengan canting dan malam batik serta warnawarna soga, sedangkan pada nglelet ini menggunakan media batang rokok dengan ampas kopi dan kreamer. Entah ide dari kopi lelet itu sendiri berawal dari mana, belum ada yang bisa memastikan dengan pasti budaya kopi lelet ini. Yang jelas, kopi lelet ini masih bertahan sampai sekarang dan bertambah peminatnya. (Wikipedia, 2013a).

Kopi Lelet adalah kopi yang khas di kota Lasem. Kopi Lelet ini identik dengan kegiatan nge-lelet, yaitu membatik dengan media batang rokok dan tintanya menggunakan lethekan kopi lelet (ampas kopi lelet atau kopi lasem yang dicampur susu krimer) (Wikipedia, 2013b). Kopi lelet itu sendiri merupakan kebiasaan masyarakat tidak hanya di kota Lasem saja, tetapi hampir sebagian besar di Kabupaten Rembang, dengan cara membatik ampas kopi pada sebatang rokok. Melalui media rokok, proses batik kopi ini diaplikasikan. Oleh karena itu, tulisan ini juga mengajak untuk melihat dari sisi lain rokok, yaitu rokok dapat menjadi penyalur kreatifitas dalam bidang seni lukis, bagi penikmat kopi dan rokok tentunya.

Jadi istilah batik disini tidak merujuk batik secara umum, yaitu membuat ukiran pada sebuah kain mori dengan menggunakan canting menggunakan malam batik, tapi lebih kepada seni membatik pada sebuah rokok yang digunakan. Ibarat kanvas dan tintanya adalah racikan kopi yang telah diaduk tadi. Proses ini yang menjadikan batik kopi di Lasem berbeda jika membeli kopi di warung-warung. Berbeda juga ketika membeli kopi di warung kopi, seperti di Surabaya-Gresik (Warung Giras), Jawa Barat (Borju) atau Jogjakarta (Angkringan). Semua kopi yang dijual seragam dan hanya menjual kopi sachet yang instan. Di Semarang pun juga mulai terpengaruh dan berdiri beberapa warung kopi lelet, karena banyak mahasiswa yang berasal dari Kabupaten Rembang menimba ilmu di Semarang, seperti: Unes, Undip, Ikip Semarang, Unisula, dan Universitas Swasta lainnya atau masyarakat Kabupaten Rembang yang berdomisili ke Semarang.

\section{Perkembangan Kopi Lelet}

Berdasarkan pengamatan saya, pergi ke warung kopi lelet layaknya sudah menjadi sebuah rutinitas yang menyenangkan bagi para warga Lasem, khususnya pria. Kopi lelet bisa ditemukan hampir di setiap sudut Kabupaten Rembang, terutama kota Lasem. Banyak peminat kopi lelet di sini. Sudah tidak menjadi rahasia lagi, kalau budaya kopi lelet ini sudah mendarah daging di kota Lasem. Para santri pun tak urung menghabiskan malam dari setelah maghrib sampai jam 9 malam kadang juga sampai malam, sambil melukis batang rokok mereka satu per satu. Bercakap-cakap dengan teman atau sekedar mendengarkan alunan musik dari Handphone. Harga satu cangkir kopi sekitar Rp 2000-3000 rupiah per gelas kopi hitam dan Rp 2500-3500 rupiah per gelas kopi susu. 


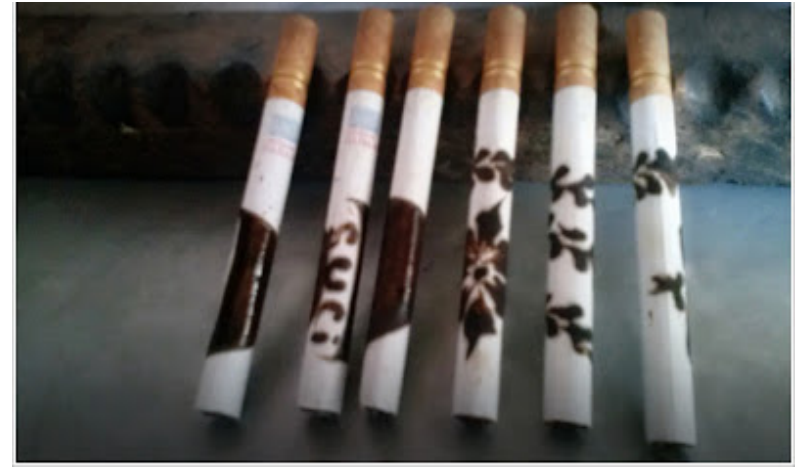

Gambar 2

Foto Kopi yang Telah di Lelet

Tidak hanya itu, perkembangan teknologi juga membuat proses pengenalan kopi lelet ini mulai dikenal secara maya. Munculnya beberapa website atau berasal dari komunitas blogger Rembang menulis artikel tentang kopi lelet Lasem ini, serta liputan dari Metro TV yang diupload juga di Youtube. Sehingga hal ini memicu pendatang atau wisatawan yang singgah sebentar di kota Lasem penasaran dan mencoba kopi lelet ini. Kemudian mereka juga menulis artikel di website masing-masing baik itu website ataupun blog-blog pribadi tentang pengalaman mereka, serta ada juga yang menjual kopi lelet bubuk yang dijual secara online.

\section{Berangkat dari Testimoni}

Kredibilitas dibangun mulai dari kesaksian positif dari beberapa konsumen yang telah mencoba sebuah produk. Mereka mempunyai kekuatan dalam membangun opini publik dan dapat menjadi instrumen dalam menarik peminat. Word of mouth adalah cara ampuh dalam dunia marketing, walaupun tradisional namun masih sangat bekerja dalam proses pembentukan branding sebuah kota (Pike, 2008:xiv). Pada bagian ini, saya membangun beberapa kesaksian tentang wisatawan atau masyarakat Lasem sendiri setelah menikmati kopi lelet ini melalui cerita di website.
"Seorang pengunjung, Dansapar mencoba untuk pertama kalinya pergi ke warung kopi di kota Rembang, dia kaget karena warung kopi disini bisa dikatakan semuanya melakukan kebiasaan yang sama, yaitu melukis batang rokok dengan ampas kopi... Proses melukis ke batang rokok juga tidak sembarangan, karena ada tahap yang perlu dipelajari disini, terutama bagi pemula...Jadi perlu beberapa minggu untuk melatih kreatifitas dalam melelet kopi ala kota Lasem ini. Informasi mengenai Warung Kopi Pak Gendut banyak didapatkan melalui dunia maya. Kalau pergi ke Lasem mencoba Kopi Lelet di Warung Kopi Pak Gendut!... Kopi Lelet ala Warung Kopi Pak Gendut! Kopi Lelet dan Warung Kopi di Lasem memang telah membudaya. Kegiatan minum kopi telah menjadi kebiasaan. Namun kebiasaan mengopi di Lasem menjadi unik dan beda karena adanya budaya kopi. Apabila rokok dan kopi di sebuah warung kopi bisa ditemukan di banyak tempat, namun budaya rokok dan kopi di warung-warung kopi di Lasem bisa menjadi sebuah identitas lain dari Lasem, menandakan satu budaya lain yang memang tidak bisa dilepaskan di Lasem. Budaya lain yang ikut ambil bagian dalam keseharian masyarakat Lasem di warung kopi bersama rokok dan kopi adalah batik (Dansapar 2012)."

Berbeda yang diutarakan Wulandari (2013), seorang perempuan penikmat kopi beropini lain. Sambil menikmati kopi, dia dimanjakan dengan atraksi membatik di permukaan rokok putih dengan ampas dari kopi lelet oleh salah satu pengunjung di warung ini. Dia yang awalnya duduk di pojok pun ikut beranjak mendekat untuk melihat lebih dekat bagaimana cara membatik atau ngelelet dengan ampas kopi. Meskipun dia bukan perokok, tetapi dia begitu menikmati hasil karya batikan di atas rokok ini dan beberapa teman membawanya pulang sebagai oleh-oleh. Menurut temannya, Mas Pop (nama sapaan) yang memang perokok, rasa rokoknya berbeda setelah dilelet karena selain rokoknya bercita 
rasa kopi, memiliki jiwa seni dan dihirup dengan damai. Hal ini menjadikan dia penasaran untuk mengetahui lebih jauh proses pembuatan kopi lelet.

Sawitri (2013) bercerita jika saat berada di Lasem, adanya sebuah pantangan untuk pergi ke warung kopi lelet. Karena dia dapat sekaligus menyelami jati diri kota Lasem dan masyarakatnya. Fenomena rokok dan lukisan ampas kopi membuktikan budaya membatik memang sudah mengalir di nadi masyarakat Lasem. Menurut Pak Toro, penggerak Forum Komunikasi Masayarakat Sejarah (Fokmas) Lasem, warung kopi lelet memainkan peran penting dalam menjaga harmonisasi di Lasem. Di warung sederhana tersebut masyarakat Jawa dan Tionghoa berinteksi, bertukar kata dan berdialektika. Lewat interaksi intens, kerukunan antar etnis di Lasem pun terus terpelihara meski generasi terus berganti.

Beberapa testimoni yang berada di website tersebut turut berkontribusi untuk memperkenalkan budaya lelet di kota Lasem dan dapat menggugah rasa penasaran bagi pengunjung dari luar kota Lasem sendiri. Meskipun demikian, budaya ini bukan hadir tanpa masalah, karena menjamurnya warung kopi di kota Lasem ini memicu terjadinya perbuatan maksiat. Seringkali warung kopi remangremang yang kurang mendapatkan perhatian dari pemerintah justru dijadikan tempat mesum bagi pengunjung, terutama para supir truk dan para pemuda atau dewasa. Biasanya warung ini menggunakan pramusaji wanita cantik dan berpakaian seksi sebagai daya tarik pengunjung.

Menurut bupati Rembang Abdul Hafidz, di Kabupaten Rembang tercatat jumlah warung kopi sekitar 900-an dan rata-rata mempekerjakan pramusaji. Jumlah tersebut tidak boleh dianggap remeh, karena dapat menjadi potensi untuk mengurangi pengagguran dan kemiskinan. Akan tetapi sebaliknya jika dibiarkan liar, tinggal menunggu waktu bisa menjadi tempat kemaksiatan (Radio Cb FM, 2011).

Beberapa testimony atau kesaksian di atas merupakan beberapa kutipan dari blog atau website yang merupakan kesan dari beberapa pengunjung. Mereka sangat kompak dalam menyuarakan jika budaya kopi lelet ini sudah menjadi kebiasaan masyarakat Lasem dan menjadikannya identitas tersendiri dari kota Lasem. Tidak hanya pesan kopi lalu diminum seperti memesan kopi di kedaikedai lainnya. Terlepas dari itu, tidak bisa dipungkiri kebiasaan masyarakat Lasem yang telah lama mendalami seni lukis batik juga menjadikan daya kreatif pelukis rokok ikut dalam melukis batang rokok dengan ampas kopi yang telah diracik. Dilihat dari perkembangannya, bisnis warung kopi di kota Lasem ini juga mulai ramai. Akan tetapi jika dibiarkan secara liar, akan adanya kejadian negatif yang menuju pada kegiatan asusila. Oleh itu, dalam pelaksanaannya warung kopi ini juga harus mendapat perhatian lebih dari pemerintah daerah dalam menangani dan mencegah terjadinya praktek tersebut, tetapi juga tidak lupa akan potensi yang dapat dikembangkan.

\section{Strategi City Branding}

Kota Lasem merupakan kota yang telah sebelumnya dikenal sebagai Kota Batik. Dapat ditemukan banyak perajin batik Lasem yang dikenal Batik Tulis Laseman di beberapa desa di Lasem sebagai perajin batik. Akan tetapi potensi ini kurang dikembangkan dan hanya mengandalkan industri rumahan dalam 
memproduksi Batik Tulis Laseman. Oleh karena itu nama yang melekat sebagai kota batik ini kurang mendapatkan perhatian yang khusus bagi penikmat kain batik, karena ternyata di Lasem kurang adanya perhatian yang lebih baik itu pemerintah ataupun pengusaha batik rumahan untuk membuat komunitas batik supaya lebih dikenal secara nasional.

Di lain sisi, kota Lasem juga terkenal akan kota santrinya. Ditambah adanya pasujudan Sunan Bonang yang juga ramai dikunjungi peziarah. Mengingat apa yang telah dikutip di atas dari seorang $\mathrm{KH}$. Mustofa Bisri (Gus Mus) yang sekarang menjabat sebagai pengasuh pondok pesantren Raudlatuth Thalibin Rembang, berpendapat jika sejak dahulu kyai dan santri maniak kopi. Ternyata dalam dunia pesantren, kopi juga digemari. Terlihat juga saat saya mengunjungi dan menikmati kopi salah satu warung kopi terkenal di kota Lasem yaitu di Pak John. Saya menemui ada beberapa santri yang memesan kopi lelet dan mulai meracik ampas kopi dan siap membatik, kemudian disusul beberapa temannya. Melalui proses sejarah panjang, bagaimana batik sudah menjadi mata pencaharian utama, khususnya wanita di kota Lasem sebagai perajin batik. Citra Lasem sebagai kota santri yang beberapa santri menyukai kopi lelet bisa dikatakan kalau batik, santri dan kopi menjadi kata kunci dalam upaya pemilihan brand yang tepat di kota Lasem.

Pada pemilihan tipe brand apa yang cocok bagi kota Lasem dan telah diuraikan di atas berdasarkan sejarah dan perkembangannya, saya mencoba menggunakan tipe asosiasi brand untuk memunculkan brand. Asosiasi brand dinyatakan pada sebuah ingatan tentang sebuah produk yang membantu konsumen dalam pengolahan informasi: "Sebuah brand adalah segala sesuatu yang "dikaitkan" pada ingatan tentang suatu brand' (Aaker dalam Pike, 2008:181). Yang paling bersifat kritis adalah asosiasi brand yang kuat, baik dan unik (Keller dalam Pike, 2008:181). Berdasarkan kutipan di atas, penggunaan asosiasi yang sebelumnya melekat pada sebuah produk dari kota Lasem yang kemudian mendapatkan proses packaging lebih kuat dan melekat untuk dijadikan sebuah brand.

Dari tiga kata kunci di atas, batik, santri dan kopi, perpaduan dari ketiganya untuk dilekatkan dan menjadi sebuah brand. Keterikatan yang telah lama dibentuk antara batik dan Lasem, dapat menghadirkan identitas sendiri ketika menyebutkan kata batik. Kedua, Lasem juga terkenal sebagai kota santri, karena banyaknya pesantren yang bisa ditemui, juga dapat menjadikan santri sebagai brand. Tapi ketika kata santri yang akan digunakan sebagai brand kota, ternyata santri ini juga menyukai kopi yang notabene sebagai budaya yang telah melekat di kota Lasem. Jadi untuk tidak membatasi pengkategorian siapa yang dapat menikmati kopi lelet sebagai karakter utama kota Lasem hanya terbatas kepada santri, maka penggunaan kata kopi lebih dipilih supaya penikmat kopi lebih universal.

Didapatkan brand yang cocok bagi kota Lasem yaitu terdiri dari kata batik dan kopi. Rekomendasi inilah yang mungkin cocok sebagai city brand baru menjadi Lasem kota batik-kopi. Brand baru ini terlihat begitu sederhana tetapi mempunyai ikatan asosiasi yang kuat terhadap ingatan konsumen yang membacanya. Bagaimana makna yang melekat pada kata batik merujuk kepada brand sebelumnya yang memberikan citraan Lasem sebagai kota Batik. Karena 
sekarang masih dalam proses sedang dikembangkannya wisata batik di kota Lasem dengan dibangun beberapa tempat khusus bagi para wisatawan yang ingin melihat proses pembuatan kain batik tulis Laseman dan bisa membeli secara langsung batik yang disukai. Sedangkan kopi itu sendiri terkait dengan rutinitas yang telah membudaya di masyarakat Lasem dan bisa ditemui tiap setelah maghrib warung kopi mulai ramai dikunjungi. Tidak bisa melepaskan kata kopi dalam pembuatan brand ini, mengingat kopi lelet adalah karakter utama dan bertindak sebagai identitas kota Lasem. Arti tanda penghubung juga memiliki makna, bagaimana penghubung ini seolah tidak bisa melepaskan pengertian batik dan kopi secara terpisah, namun lebih kepada proses penghubungan kedua budaya ini menjadi satu, Batik-kopi. Batik di sini juga memiliki makna yang homonim dengan batik yang pertama. Batik dengan penghubung ini lebih merujuk kepada kegiatan membatik kopi di batang rokok sebagai kanvas dengan ampas kopi sebagai tintanya.

Penggunaan batik-kopi disini, saya tidak menggunakan kata penghubung "dan" dalam menyambung brand Lasem adalah kota batik-kopi. Hal ini dikhawatirkan dengan menggunakan penghubung ini akan membatasi karakter dari citraan yang terbentuk. Jadi Lasem adalah kota batik dan kopi. Ada sebuah gap yang memisahkan keduanya, yaitu kota Lasem yang dikenal sebagai batik ternyata terkenal juga di bidang produksi kopi. Oleh karena itu, saya cenderung menggunakan penghubung "_" dalam menghubungkan jargon Lasem Adalah Kota Batik-Kopi. Artinya Lasem adalah kota yang dikenal sebagai kota penghasil batik dan juga terkenal sebagai kota seni membatik batang rokok dengan tinta kopi.

\section{Potensi Pengembangan Hasil Produksi}

\section{a. Batik}

Batik yang menjadi primadona di kota Lasem, dapat dikembangkan gerai-gerai atau centra batik sebagai pusat pameran kain batik dan pusat produksi. Dengan cara ini dikumpulkannya para perajin batik pada sebuah ruang seperti perkumpulan, sehingga ini akan mempermudah wisatawan yang ingin belajar atau melihat secara langsung proses pembuatan batik Lasem dan disediakan tempat jualan batik sebagai sovenir sebagai oleh-oleh, dipakai sendiri atau dijual kembali.

\section{b. Kopi lelet}

Dalam perkembangan kota Lasem sebagai kota dengan karakter masyarakatnya yang telah membudaya dan menjadi lifestyle (gaya hidup), kopi lelet telah menjadi budaya bagi masyarakat kota Lasem. Akan tetapi, efek buruk yang dapat juga menjadi sisi negatif dari kopi lelet ini. Pada segmentasi umur, jika melihat perkembangan yang ada pada saat ini, jumlah perokok aktif terus meningkat bahkan tingkatan perokok mulai merambah di usia muda, seperti SMP dan SMA. Karena kopi lelet ini sangat cocok dengan dikombinasikan dengan rokok, maka sasaran pasar yang ideal untuk segmentasi umur adalah di atas 18 tahun. Walaupun sangat kontroversial, harus tetap ada batasan dan sesuai dengan aturan bahwa seseorang dikatakan boleh merokok adalah jika umur mereka di atas 18 tahun demi mengurangi resiko anggapan negatif tentang kopi lelet ini yang mengharuskan penikmatnya merokok. Jadi kopi lelet ini perlu ditekankan bahwa kopi lelet bukanlah pendorong seseorang mengkonsumsi rokok, namun berangkat dari perokok itu sendiri yang menyukai kopi. 
Kenyataannya seorang perokok pasti menyukai kopi. Sedang penikmat kopi belum tentu perokok. Batasannya memang sangat tipis, tapi perlu ada batasan umur supaya citra kopi lelet ini tetap terlihat baik dan tanpa kesan negatif. Demi mengurangi resiko tersebut, maka sangat ideal segmentasi dari konsumen adalah yang telah berumur 18 tahun ke atas sudah dianggap dewasa.

Terakhir, tanpa mengesampingkan segmentasi jender, penikmat kopi lelet yang selama ini didominasi oleh kaum pria, namun ternyata ada testimoni dari Wulandari, seorang pecinta kopi, tidak risih untuk mencoba kopi lelet ini, justru malah menginginkan kembali ke Lasem untuk dapat belajar nglelet. Belajar nglelet bukan berarti mendorong Wulandari untuk menjadi perokok, namun bagaimana dia menikmati proses melukis di batang rokok adalah hal yang unik dan butuh tantangan. Itu artinya, tidak ada batasan bagi wanita yang ingin menikmati kopi lelet ini. Khususnya bagi wanita pecinta kopi dan wanita perokok. Dalam mereduksi anggapan negatif oleh masyarakat tentang wanita yang mencoba kopi lelet selalu merokok, nanti akan dibahas lebih lanjut pada bagian kepariwisataan.

\section{Kepariwisataan}

Untuk membuat kota yang akan tetap dikunjungi dan menarik banyak wisatawan pastilah harus didukung dengan tempat untuk wisata. Kenyamanan dalam mengunjungi tempat wisata akan menjadikan tempat tersebut menjadi tempat favorit yang akan dikunjungi wisatawan di lain kesempatan. Packaging yang lebih baik dari sebelumnya menjadi usaha untuk menarik pengunjung dan membeli produk. Pengemasan Kepariwisataan (Tourism Packaging) tidak melibatkan pengemasan secara fisik apa saja yang terkait dengan produksi produk. Namun lebih kepada proses dimana sebuah produk untuk wisatawan dengan tambahan pelayanan yang diinginkan pengunjung. Pengemasan ini kemudian akan dipromosikan kepada wisatawan dan mereka akan membeli wisata yang mereka inginkan.

Pengemasan kepariwisataan menjadi daya tarik tersendiri, bagaimana wisatawan dapat memilih paket wisata mana yang akan mereka pilih. Karena hal ini akan membuat perjalanan wisatawan lebih terorganisir dan menghemat waktu. Selain itu mereka juga dapat membeli sovenir terkait dengan tempat wisata yang mereka inginkan. Seperti yang diungkapkan Kolb dalam bukunya, Tourism Marketing for Cities and Town, bahwa untuk wisatawan, dalam membeli sebuah paket perjalanan akan memberikan keuntungan harga. Harga adalah perhatian utama bagi kebanyakan wisatawan, karena mereka harus mempunyai uang sesuai dengan perjalanan akan mereka tempuh ... Sebuah paket perjalanan yang meliputi daya tarik, transportasi dan tempat menginap akan mengurangi resiko saat tidak mengetahui berapa uang yang harus dikeluarkan (Kolb, 2006:182). Menurut pusat studi di UGM bahwa motivasi wisata minat khusus bertujuan untuk mendapatkan/mengeksplorasi sesuatu yang baru/unik (novelty seeking). Wisata minat khusus ini memiliki unsurunsur REAL travel, yaitu: Rewarding, Enriching, Adventuresome, dan Learning). REAL travel ini bermanfaat untuk memberikan pengalaman berkualitas dimanifestasikan dalam bentuk wisata aktif dalam suatu perjalanan yang melibatkan langsung wisatawan, baik secara fisik, mental, dan emosional, dengan karakteristik objek-objek yang dikunjunginya (Studi Pengembangan 
Wisata Minat Khusus, UGM, 1997; Mastika, 2018). Berdasarkan teori di atas tersebut tentang pentingnya pengemasan kepariwisataan sehingga menarik wisatawan, disini saya akan mencoba mengemas sebuah paket pariwisata untuk menarik pengunjung, terutama bagi pengunjung luar kota dan luar pulau.

\section{Tempat Wisata}

Sebelum melakukan pengemasan tujuan tempat wisata, pertama kali adalah pengkategorian tempat mana saja yang cocok sebagai tempat wisata di kota Lasem. Beberapa tempat yang dapat menarik minat wisatawan sesuai dengan keinginan mereka.

\section{Wisata Batik}

Tujuan utama yang pertama sebagai tempat wisata adalah tempat perajin batik. Di sini khusus bagi wisatawan yang ingin mengetahui cara membatik, atau praktek belajar membatik sendiri, ataupun membeli beberapa potong batik untuk dipakai sendiri atau oleh-oleh. Wacananya pemerintah kota Lasem akan membuat beberapa bangunan yang nantinya perajin-perajin batik akan dikelompokkan menjadi satu tempat.

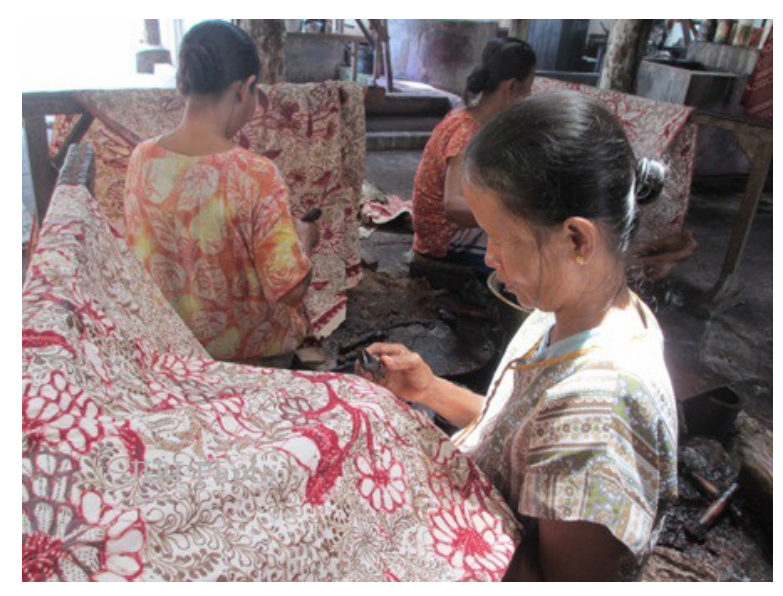

Gambar 3.

Batik Laseman
Oleh karena itu, kedepannya agar dapat direalisasikan pembangunan tempat wisata batik yang nantinya akan dikenal sebagai kampung batik. Terinspirasi seperti di kota Pare yang dikenal sebagai Kampung Inggris-nya, kota Lasem wacananya akan dibuka kursus cara membatik baik untuk wanita atau lakilaki, sehingga perkembangan batik dari Lasem menjadi begitu dikenal secara luas. Bagaimana setelah Kampung Batik terwujud kedepannya di sekitar kawasan tersebut juga akan dibangun hotel, restoran, dan toko-toko sehingga tidak hanya mendapatkan pendapatan kota tapi juga akan meningkatkan perekonomian masyarakat sekitarnya.

\section{Kopi Lelet}

Tempat wisata yang kedua ini adalah kopi lelet. Prosesnya sama dengan yang saya wacanakan pada wisata batik. Nantinya akan dibangun satu tempat sebagai pusat, dimana semua warung kopi lelet berkumpul menjadi satu. Layaknya kampung batik, di tempat ini juga akan dijadikan kampung lelet. Melalui brosurbrosur yang juga dibuat tentang pembentukan discourse kampung lelet yang akan dibangun dengan tagline "cara baru menikmati kopi." Harapan kedepannya brosur ini bukan hanya sebuah tagline namun akan menciptakan trend baru cara meminum kopi yang unik dengan membatik kopi di atas batang rokok. Dapat diprediksi nantinya kota Lasem akan dibanjiri pengunjung baik dari luar kota dan luar jawa. Bisa saja kota Lasem juga akan diserbu wisatawan manca negara. Karena kebanyakan wisatawan manca negara menyukai kopi dan rokok, apalagi rokok di Indonesia sangat mahal jika dijual di luar negeri khususnya Eropa mencapai 4 Euro per bungkus. Maka, kota Lasem akan menjadi sangat cocok untuk wisatawan manca mengunjungi kota kopi ini. 
Nantinya untuk mengurangi anggapan kota Lasem sebagai kota untuk mengajarkan merokok, nantinya akan dibuatkan juga tempat khusus wanita yang pecinta kopi. Jadi tidak hanya memihak kepada kaum pria namun penikmat kopi wanita juga bisa ikut menikmati kopi Lasem dan jika ingin belajar membatik kopi bisa dialihkan media kanvasnya bukan menggunakan batang rokok tapi bisa diganti dengan kayu yang telah diukir dan dilapisi kain. Sehingga tidak ada diskriminasi kepada wanita.

\section{Wisata Sejarah}

Kota Lasem juga kaya akan warisan sejarah. Mulai dari awal sejarah Majapahit dengan beberapa peninggalannya, sejarah Tionghoa di Lasem dengan Klenteng-klenteng kuno bahkan tertua di Jawa hingga sebuah vihara cantik yang memiliki pemandangan spektakuler kota Lasem (Bandanaku, 2012). Kota Lasem juga dikenal sebagai Thionghoa kecil karena peninggalan sejarahnya ini. Akan tetapi tidak hanya itu, wisata religi pun juga ada, bagi umat muslim ada pasujudan Sunan Bonang di kota Bonang (hanya beberapa kilometer dari kota Lasem). Di sini bisa ditemukan batu bekas tempat sunan Bonang bersujud, ada juga temoat tinggalnya sunan dan makam kuno yang bisa ditemui. Ternyata Lasem juga dapat dikembangan di ranah wisata sejarah, yaitu sejarah Bangunan Cina dan wisata religi.

\section{Wisata Kuliner}

Di kota Lasem juga memiliki sebuah makanan kuliner yang terkenal. Yaitu Lontong Tuyuhan yang terletak di desa Tuyuhan. Makanan yang terdiri dari lontong, dengan sayur yang mirip opor namun menggunakan santan dan agak pedas dengan ramuan yang khas.
Lauknya dengan ayam kampung, lengkap dengan jeroan, gending, sayap dan paha dan minumnya disediakan teh botol dan es kelapa muda. Tempat kuliner ini mudah dijangkau dan dekat dengan pusat kota Lasem. Letaknya berjauhan dengan pemukiman warga, sehingga pengunjung dapat merasa nyaman. Ditambah juga pemandangan sekitar yang jarang ditemui di kota besar, yaitu sekelilingnya terdapat persawahan dan gunung Lasem yang dapat dilihat dari sini. Berjejeran menjadi satu beberapa penjual lontong tuyuhan. Bangunan yang khas pedesaan dengan bangku dari anyaman bambu dan atap menggunakan pondasi bambu dan genting, tanpa menggunakan jendela seperti gazebo.

\section{Wisata Pantai}

Di kota Lasem juga terdapat pantai yang juga menjadi primadona. Ada dua pantai yang sering di kunjungi baik dari masyarakat Lasem sendiri atau di luar Lasem. Pantai Caruban, pantai yang lokasinya $1 \mathrm{~km}$ di belakang terminal Lasem. Masih sangat alami dan belum tersentuh oleh pemerintah untuk dikembangkan sebagai tempat wisata. Hanya ada gapura dan beberapa ruko di lokasi pantai, itu pun tidak terawat. Pantai yang ombaknya tidak terlalu besar, sangat cocok untuk keluarga yang ingin berlibur dan mengajak anakanaknya bermain disini dengan ban atau berenang.Kedua adalah pantai Binangun, pantai yang lokasinya dekat dengan kota Lasem kira-kira $5 \mathrm{~km}$. Pantai yang satu lokasi dengan pasujudan sunan Bonang ini sudah mulai dikembangkan dengan dibangunnya Rest Stop Area untuk pengunjung atau tempat beristirahat saat perjalanan. $\mathrm{Di}$ sini disuguhi pemandangan laut yang indah dan sunset yang tidak kalah dengan pantai Kuta. Disamping itu pengunjung juga dapat 
memancing di laut lepas dengan menyewa perahu.

\section{Paket Wisata}

Selain dari wisata batik dan kopi, ada beberapa tempat wisata, mulai dari wisata sejarah, religi, pantai sampai kuliner. Harga adalah yang pertama saat memilih tempat wisata. Pengemasan menjadi paket wisata juga akan saya bedakan menjadi tiga macam, yaitu paket hemat yang dikhususkan bagi segmen backpaker dan paket keluarga bagi segmen menengah, sedangkan deluxe dikhususkan bagi segmen ekonomi ke atas. Strategi ini diharapkan akan mampu untuk menyesuaikan keinginan pengunjung dan sesuai dengan kemampuan ekonominya. Paket hemat dan keluarga sangat menarik untuk ditawarkan bagi para wisatawan terutama wisatawan ekonomi menengah ke bawah. Sedangkan paket deluxe dikhususkan bagi ekonomi atas terutama untuk relasi bisnis atau wisatawan manca negara. Semua paket ini antinya juga akan satu paket dengan transportasi, hotel atau penginapan, makan, dan atau tambahan guide.

\section{Pusat Informasi}

Pusat informasi juga hal yang tidak boleh terlupakan dalam membangun tempat wisata. Pusat ini digunakan terutama para backpacker yang ingin mengetahui ada tempat wisata apa saja yang ada di kota Lasem. Seperti di pulau Bali, banyak di temukan pusat informasi di setiap kota wisata. Oleh karena itu, akan disediakan pusat informasi di tiap-tiap tempat wisata. Nantinya pusat informasi ini memberikan peta wisata gratis kota Lasem dan buku panduan dan sejarah untuk menemani perjalanan di kota Lasem. Melalui pelayanan ini, secara tidak langsung peta ini akan membawa pengunjung baru dari pengunjung sebelumnya. Ini juga menerapkan strategi mouth to mouth, dimana wisatawan tidak hanya ingin menikmati tempat wisata tapi juga jasa atau pelayanan yang disediakan bagi wisatawan. Seperti peta wisata yang dapat diproduksi dalam bentuk tidak hanya cetak, tetapi juga digital.

\section{KESIMPULAN}

Berdasarkan analisis di atas, dapat ditarik dua kesimpulan. Pertama, meskipun masyarakat telah mengetahui di internet tentang kota Lasem, akan tetapi infrastruktur belum didukung untuk menghadirkan potensi kota Lasem untuk budaya membatik (batik secara harfiah dan batik sebagai lelet). Karena masyarakat masih secara mandiri atau membuka warung-warung kecil untuk membuka warung kopi dan industri batik juga masih rumahan.

Kedua, potensi yang dapat dikembangkan adalah pemerintah kota Lasem dapat mencanangkan pemilihan branding yang tepat untuk kota Lasem. Tidak lupa pengemasan wisata dengan beberapa paket wisata juga merupakan strategi untuk menarik pengunjung. Selanjutnya, pembagian tempat wisata juga dilakukan supaya lebih mudah dalam menentukan tujuan mana wisata yang akan dituju di kota Lasem. Terakhir adalah pembuatan kebijakan dan peraturan untuk pembentukan tim dalam pelaksanaan proyek ini supaya berjalan dengan baik dan sesuai rencana. Jadi rekomendasi city branding kota Lasem Kota Batik-Kopi dinilai akan lebih mendatangkan pengunjung dalam menciptakan brand yang lebih emosional dan membangun citra Lasem, ternyata bukan hanya kota Batik tetapi kota Kopi. 


\section{REFERENSI}

\section{Buku:}

Kolb, Bonita M. 2006. Tourism Marketing for Cities and Towns. USA: Elsevier, 2006.

Mastika, Ketut I. 2018. "Pengembangan Ekowisata Berwawasan Kearifan Lokal di Wilayah Eks Karesidenan Besuki, Jawa Timur." Jumpa, 4(2):240-252.

Pike, Steven. 2008. Destination Marketing: An Integrated Marketing Communication Approach. Hungary: Elsevier.

\section{Website:}

CB FM. 2011. "Keberadaan warung kopi Lelet perlu ditertibkan." Radio CBFM. Diakses tanggal 6 November 2013. (http://cbfmrembang.blogspot.co m/2011/11/keberadaan-warungkopi-lelet-perlu.html).

Bandanaku, Elvi. 27 Maret 2012. "Menjadikan Lasem 'Heritage City' Pertama di Indonesia." Kompasiana. Diakses tanggal 16 November 2013. (http://sosbud.kompasiana.com/2 012/03/27/menjadikan-lasemheritage-city-pertama-diindonesia-449707.html)

Dansapar. 2012. "Lengket ala Kopi Lelet. 26 Desember 2012." Dansapar. Diakses tanggal 6 November 2013. (http://www.dansapar.com/ 2012/12/26/lengket-ala-kopi-lelet/).

Irin, Sohirin. 01 Januari 2013. "Lelet, Cerita Minum Kopi yang Tak Pernah Mati." Diakses tanggal 6 November 2013. (http://sohirinirin.blogspot.com/2013/01/leletcerita-minum-kopi-yang-takpernah.html)

Toif, Maliki. 28 Mei 2013. "Sejarah Kopi Lelet Lasem Rembang." Diakses tanggal 6 November 2013. (http://rembangonline.blogspot.c om/2013/05/ sejarah-kopi-leletlasem-rembang.html)

Sawitri, Yusmei. 2013. "Keunikan Warung Lelet Kopi Bagian II." Solopos. Diakses pada tanggal 6 November 2013.

(http://www.solopos.com/2013/04 /16/keunikan-warung-kopi-lelet-dilasem-bagian-ii-396918).

Wikipedia. 2013a. "Lasem, Rembang." Wikipedia. Diakses tanggal 6 November 2013. (http://id. wikipedia.org/wiki/Lasem,_Remba ng).

Wikipedia. 2013b. "Kopi Lelet." Wikipedia. Diakses tanggal 6 November 2013. (http://id.wikipedia.org/wiki/Kopi_ lelet).

Wulandari, Nenny. 2013. "Kesengsem Kopi Lasem." Diakses pada tanggal 6 November 2013. (http://nennywulandari.wordpress .com/2013/04/02/ kesengsem-kopilasem/)

\section{Video:}

Arie Saputro Channel. Video Youtube :KOPI LELET REMBANG. Diakses tanggal 6 November 2013. (http://www.youtube.com/watch? $v=$ hqkHeibMGyg)

Nu ZulfikRock Channel Pesona Kopi Lelet Lasem by MetroTv. Diakses tanggal 6 November 2013. (http://www.youtube.com/watch? $v=014 Y_{3}$ CubPEQ)

\section{Apendiks Gambar:}

Gbr 1 Sumber Google Maps

Gbr 2 Sumber Dansapar.com

Gbr 3 Sumber SoloPos.com 